\title{
Article
}

\section{Glucose Detection of 4-Mercaptophenylboronic Acid-Immobilized Gold-Silver Core-Shell Assembled Silica Nanostructure by Surface Enhanced Raman Scattering}

\author{
Xuan-Hung Pham ${ }^{1}{ }^{\mathbb{D}}$, Bomi Seong ${ }^{1}$, Eunil Hahm ${ }^{1}$, Kim-Hung Huynh ${ }^{1}$, Yoon-Hee Kim ${ }^{1}$, Jaehi Kim ${ }^{1}$, \\ Sang Hun Lee ${ }^{2}$ and Bong-Hyun Jun $1, * \mathbb{B}$ \\ 1 Department of Bioscience and Biotechnology, Konkuk University, Seoul 143-701, Korea; \\ phamricky@gmail.com (X.-H.P.); iambomi33@konkuk.ac.kr (B.S.); greenice@konkuk.ac.kr (E.H.); \\ huynhkimhung82@gmail.com (K.-H.H.); hilite2201@naver.com (Y.-H.K.); susia45@gmail.com (J.K.) \\ 2 Department of Chemical and Biological Engineering, Hanbat National University, Daejeon 34158, Korea; \\ sanghunlee@hanbat.ac.kr \\ * Correspondence: bjun@konkuk.ac.kr; Tel.: +82-2-450-0521
}

check for updates

Citation: Pham, X.-H.; Seong, B.; Hahm, E.; Huynh, K.-H.; Kim, Y.-H.; Kim, J.; Lee, S.H.; Jun, B.-H. Glucose Detection of 4-Mercaptophenylboronic Acid-Immobilized Gold-Silver Core-Shell Assembled Silica Nanostructure by Surface Enhanced Raman Scattering. Nanomaterials 2021, 11, 948. https://doi.org/10.3390/ nano11040948

Academic Editors: Barbara Fazio,

Cristiano D'Andrea and

Paolo Matteini

Received: 27 February 2021

Accepted: 4 April 2021

Published: 8 April 2021

Publisher's Note: MDPI stays neutral with regard to jurisdictional claims in published maps and institutional affiliations.

Copyright: (C) 2021 by the authors Licensee MDPI, Basel, Switzerland. This article is an open access article distributed under the terms and conditions of the Creative Commons Attribution (CC BY) license (https:/ / creativecommons.org/licenses/by/ $4.0 /)$.

\begin{abstract}
The importance of glucose in many biological processes continues to garner increasing research interest in the design and development of efficient biotechnology for the sensitive and selective monitoring of glucose. Here we report on a surface-enhanced Raman scattering (SERS) detection of 4-mercaptophenyl boronic acid (4-MPBA)-immobilized gold-silver core-shell assembled silica nanostructure $\left(\mathrm{SiO}_{2} @ \mathrm{Au} @ \mathrm{Ag} @ 4-\mathrm{MPBA}\right)$ for quantitative, selective detection of glucose in physiologically relevant concentration. This work confirmed that 4-MPBA converted to 4-mercaptophenol (4-MPhOH) in the presence of $\mathrm{H}_{2} \mathrm{O}_{2}$. In addition, a calibration curve for $\mathrm{H}_{2} \mathrm{O}_{2}$ detection of $0.3 \mu \mathrm{g} / \mathrm{mL}$ was successfully detected in the range of 1.0 to $1000 \mu \mathrm{g} / \mathrm{mL}$. Moreover, the $\mathrm{SiO}_{2} @ \mathrm{Au} @ \mathrm{Ag} @ 4-\mathrm{MPBA}$ for glucose detection was developed in the presence of glucose oxidase (GOx) at the optimized condition of $100 \mu \mathrm{g} / \mathrm{mL}$ GOx with 1-h incubation time using $20 \mu \mathrm{g} / \mathrm{mL} \mathrm{SiO}_{2} @ \mathrm{Au} @ \mathrm{Ag} @ 4-\mathrm{MPBA}$ and measuring Raman signal at $67 \mu \mathrm{g} / \mathrm{mL} \mathrm{SiO}_{2} @ \mathrm{Au} @ \mathrm{Ag}$. At the optimized condition, the calibration curve in the range of 0.5 to $8.0 \mathrm{mM}$ was successfully developed with an LOD of $0.15 \mathrm{mM}$. Based on those strategies, the SERS detection of glucose can be achieved in the physiologically relevant concentration range and opened a great promise to develop a SERS-based biosensor for a variety of biomedicine applications.
\end{abstract}

Keywords: surface enhanced Raman scattering; gold-silver core-shell; gold-silver core-shell assembled silica nanostructure; hydrogen peroxide; glucose detection; 4-mercaptophenylboronic acid

\section{Introduction}

Today, diabetes mellitus is a global problem issue with approximately 200 million people worldwide. It is of the principal causes of morbidity and disability and is largely responsible for kidney failure, heart disease, and so on [1]. A monitoring of blood glucose is of important for diabetes care [2]. Therefore, the development of a simple, rapid, and accurate method for glucose detection is highly essential, because blood glucose level is closely associated with diabetes, and hypoglycemia [3,4]. Various methods for glucose detection have been reported, including high-performance liquid chromatography (HPLC) [5], colorimetric detection [6-10], electrochemical detection [11-13], fluorescence detection [14-16], and surface enhanced Raman scattering (SERS) [17-23]. Compared with HPLC, SERS exhibited significant advantages, such as rapid, non-destructive, molecular fingerprinting, ultrasensitive, and selectivity [24-27]. Therefore, various nanoparticles (NPs) such as silver and gold nanostructures have been developed as SERS substrates for glucose detection [17-21].

However, a low affinity with metal surface and Raman scattering cross-section of polarizability limited the detection of glucose by SERS [17,22,28,29]. To achieve a high 
affinity and selectivity for glucose, a various boronic acid-based Raman reporter have been used to capture glucose selectively on the substrate [17,19,28-33]. Most of those studies mainly focused on the specific binding of glucose with the boronic acid motif in 4-MPBA, leading to a significant increase in the absolute intensity of the SERS signal of 4-MPBA, which was ascribed to the orientation change and the charge transfer effect [17-19,21,34]. An active SERS substrate based on Ag@4-MPBA nanorod was reported for quantitative detection of glucose [17]. However, the Ag nanorods preparation can sometimes be complicated. On the other hand, the self-condensation of 4-MPBA in order to form anhydride due to the association of $\mathrm{OH}$ - with 4-MPBA in various $\mathrm{pH}$ media affects the binding of glucose through the formation of esters, which may lead to the properties of the functional molecules being different from those in a solution [18]. Furthermore, the calculation of the peak area of SERS band was so complicated, resulting in a narrow dynamic linear range of glucose concentration. Furthermore, the composite of $\mathrm{Au}$ nanoparticles and Porphyrin-Based Metal-Organic Framework for SERS was used to detect glucose with high selectivity and sensitivity [35]. However, the Porphyrin-Based Metal-Organic Framework (Cu-TCPP(Fe) MOF using surfactant caused the binding of surfactant on the surface of MOF nanosheet and blocked some the actives sites of MOFs [36]. It results in the difficulty in synthesizing well-dispersed 2D-MOF nanosheets without blocking their active sites.

Recently, our group developed a gold-silver core-shell assembled silica nanostructure $\left(\mathrm{SiO}_{2} @ \mathrm{Au} @ \mathrm{Ag}\right)$ based on the Au-seed-mediated growth of $\mathrm{Ag}$ on the surface of a $\mathrm{SiO}_{2}$ NP template. The presence of $\mathrm{Au}$ seeds facilitates and allows for the precise control of the distance and uniform of the $\mathrm{Ag}$ shell on $\mathrm{SiO}_{2} \mathrm{NPs}$ as well as tuning the optical property of $\mathrm{SiO}_{2} @ \mathrm{Au} @ \mathrm{Ag}$ in the visible to near IR region [37-39]. The presence of the silica template facilitates the density, size, and shape, and the nanogap of $\mathrm{Au}-\mathrm{Au}$ on the $\mathrm{SiO}_{2}$ surface was easily controlled by $\mathrm{SiO}_{2}$ core, and generating a homogenous SERS substrate of $\mathrm{SiO}_{2} @ \mathrm{Au} @ \mathrm{Ag}$ [39]. As a result, a high-strength and reliable $\mathrm{SiO}_{2} @ \mathrm{Au} @ \mathrm{Ag}$ based-SERS substrates with high reproducibility and $4.2 \times 10^{6}$ fold-enhancement as compared to without the nanomaterial was developed for the enzyme-linked immunosorbent assay (ELISA) [40,41]. Simultaneously, a Raman reporter was also immobilized between the $\mathrm{Au}$ and Ag layer to play the role of an internal standard for the accurate detection of the pesticide thiram [42-44]. However, their use in SERS detection for glucose requires further investigation. In this study, a sensitive and selective analytical method using the basic structure of $\mathrm{SiO}_{2} @ \mathrm{Au} @ \mathrm{Ag}$ NPs incubated in 4-MPBA and enzyme glucose oxidase was developed for glucose detection using SERS. The evaluation of the SERS band toward glucose level was calculated by the ratio of SERS intensity of intrinsic internal standard 4-MPBA, which was simpler than that based on the peak area of SERS bands.

\section{Materials and Methods}

\subsection{Chemicals and Reagents}

Tetraethylorthosilicate (TEOS), 3-aminopropyltriethoxysilane (APTS), silver nitrate $\left(\mathrm{AgNO}_{3}\right)$, chloroauric acid $\left(\mathrm{HAuCl}_{4}\right)$, tetrakis(hydroxymethyl)phosphonium chloride (THPC), ascorbic acid (AA), polyvinylpyrrolidone (PVP), phosphate buffer saline (PBS), Tween 20, 4-mercaptophenylboronic acid (4-MPBA), 4-mercaptophenol (4-MPhOH), 4methylbenzenethiol (4-MBT), thiophenol, 4-glucose, hydrogen peroxide $\left(\mathrm{H}_{2} \mathrm{O}_{2}\right)$, and glucose oxidase (GOx) were purchased from Sigma-Aldrich (USA). Ethanol (EtOH) and aqueous ammonium hydroxide $\left(\mathrm{NH}_{4} \mathrm{OH}, 27 \%\right)$ were purchased from Daejung (South Korea); and ultrapure water $(18.2 \mathrm{M} \Omega \mathrm{cm})$ was produced by a Millipore water purification system (EXL water purification; Vivagen Co., Seongnam, Gyeonggi-do, Korea).

\subsection{Preparation of $\mathrm{SiO}_{2} @ A u @ A g$}

The $\mathrm{SiO}_{2} @ \mathrm{Au} @ \mathrm{Ag}$ NPs were prepared in accordance with the steps outlined in [38]. The $\mathrm{SiO}_{2} @ \mathrm{Au}$ NPs were prepared by incubating $10 \mathrm{~mL}$ of $\mathrm{Au} \mathrm{NP}$ suspension with $2 \mathrm{~mL}$ of aminated silica NPs overnight. The colloids were centrifuged and washed thoroughly using 
EtOH. The NPs were then re-dispersed in $2.0 \mathrm{~mL}$ of complete EtOH to obtain $1 \mathrm{mg} / \mathrm{mL}$ $\mathrm{SiO}_{2} @ \mathrm{Au} \mathrm{NPs}$ in $\mathrm{EtOH}$.

The $\mathrm{SiO}_{2} @ \mathrm{Au} @ \mathrm{Ag} \mathrm{NPs}$ were prepared in an aqueous medium via the reduction and deposition of $\mathrm{Ag}$ using ascorbic acid onto $\mathrm{SiO}_{2} @ \mathrm{Au}$ NPs in PVP. Moreover, $200 \mu \mathrm{L}$ of $\mathrm{SiO}_{2} @ \mathrm{Au}(1000 \mu \mathrm{g} / \mu \mathrm{L})$ was briefly dispersed in $9.8 \mathrm{~mL}$ of water that contained $10 \mathrm{mg}$ of PVP, which was kept still for $30 \mathrm{~min}$. Thereafter, $20 \mu \mathrm{L}$ of silver nitrate $(10 \mathrm{mM})$ was added to the suspension, followed by the addition of $40 \mu \mathrm{L}$ of ascorbic acid (10 mM). The suspension was incubated for 15 min to completely reduce the $\mathrm{Ag}^{+}$ions to $\mathrm{Ag}^{0}$. By repeating the reduction steps, the final $\mathrm{AgNO}_{3}$ concentration of $300 \mu \mathrm{M}$ was controlled. The $\mathrm{SiO}_{2} @ \mathrm{Au} @ \mathrm{Ag}$ NPs were obtained by the centrifugation of the suspension at $8500 \mathrm{rpm}$ for $15 \mathrm{~min}$, then the NPs were washed thoroughly using $\mathrm{EtOH}$ to remove any excess reagent. The $\mathrm{SiO}_{2} @ \mathrm{Au} @ \mathrm{Ag} \mathrm{NPs}$ were then re-dispersed in $1 \mathrm{~mL}$ of absolute $\mathrm{EtOH}$ to obtain a $200 \mu \mathrm{g} / \mathrm{mL} \mathrm{SiO}_{2} @ \mathrm{Au} @ \mathrm{Ag} \mathrm{NP}$ suspension.

\subsection{Adsorption of 4-MPBA on the Surface of $\mathrm{SiO}_{2} @ A u @ A g$}

To adsorb 4-MPBA on the surface of $\mathrm{SiO}_{2} @ \mathrm{Au} @ \mathrm{Ag}$ NPs, $500 \mu \mathrm{L}$ of $2 \mathrm{mM}$ 4-MPBA solution in EtOH was incubated with $500 \mu \mathrm{L}$ EtOH contained $20 \mu \mathrm{g} \mathrm{SiO}{ }_{2} @ \mathrm{Au} @ \mathrm{Ag}$ NP for $1 \mathrm{~h}$ at $25^{\circ} \mathrm{C}$, followed by centrifugation for $15 \mathrm{~min}$ at 15,000 rpm to obtain the NP suspension. The prepared NPs were washed thoroughly using PBS containing $0.1 \%$ Tween 20 (PBST) to remove any excess reagent. The $\mathrm{SiO}_{2} @ \mathrm{Au} @ \mathrm{Ag} @ 4-\mathrm{MPBA}$ was then re-dispersed in $100 \mu \mathrm{L}$ of $\mathrm{EtOH}$, to obtain a $200 \mu \mathrm{g} / \mathrm{mL} \mathrm{SiO}_{2} @ \mathrm{Au} @ \mathrm{Ag} @ 4-M P B A$ suspension.

\subsection{Behavior of $\mathrm{SiO}_{2} @ A u @ A g @ 4-M P B A$ in the Presence of Hydrogen Peroxide}

$100 \mu \mathrm{L}$ of PBST containing $20 \mu \mathrm{g} \mathrm{SiO} \mathrm{O}_{2} @ \mathrm{Au} @ \mathrm{Ag} @ 4-\mathrm{MPBA}$ was added incubated with $100 \mu \mathrm{L}$ of $\mathrm{H}_{2} \mathrm{O}_{2}$ at various concentration for $1 \mathrm{~h}$ at $25^{\circ} \mathrm{C}$, followed by centrifugation for $15 \mathrm{~min}$ at 15,000 rpm to obtain the NP suspension. The prepared NPs were washed thoroughly using PBST to remove any excess reagent. The prepared NPs was then redispersed in $100 \mu \mathrm{L}$ of PBST, to obtain a $200 \mu \mathrm{g} / \mathrm{mL}$ NPs suspension.

\subsection{Glucose Detection of $\mathrm{SiO}_{2} @ A u @ A g @ 4-M P B A$}

One hundred microliters of PBST containing $20 \mu \mathrm{g} \mathrm{SiO} \mathrm{O}_{2} @ \mathrm{Au} @ \mathrm{Ag} @ 4-\mathrm{MPBA}$ was added, incubated with $100 \mu \mathrm{L}$ PBST that contained various concentrations of glucose, and $100 \mu \mathrm{L}$ of GOx for $1 \mathrm{~h}$ at $25^{\circ} \mathrm{C}$, followed by centrifugation for $15 \mathrm{~min}$ at $15,000 \mathrm{rpm}$ to obtain the NP suspension. The prepared NPs were washed thoroughly using PBST to remove any excess reagent. The prepared NPs was then re-dispersed in $100 \mu \mathrm{L}$ of PBST, to obtain a $200 \mu \mathrm{g} / \mathrm{mL}$ NPs suspension.

\subsection{SERS Measurement}

To obtain the surface-enhanced Raman spectra, a micro-Raman system with a 10-mW 532-nm diode-pumped solid-state laser excitation source and an optical microscope (BX41, Olympus, Tokyo, Japan) was utilized. The SERS signals were collected with a backscattering geometry using an objective lens with a magnification of $10 \times(0.90 \mathrm{NA}$, Olympus, Tokyo, Japan). The selected sites were measured randomly, and all the SERS spectra were integrated over a period of $5 \mathrm{~s}$. The size of the laser beam spot was approximately $2.1 \mu \mathrm{m}$, and the SERS spectrum was obtained within the wavenumber range of $300-1700 \mathrm{~cm}^{-1}$.

\section{Results and Discussion}

In this study, $\mathrm{SiO}_{2} @ \mathrm{Au} @ \mathrm{Ag}$ was first immobilized by 4-MPBA as a Raman reporter and labeling molecule. Then this suspension was added into glucose solution in the presence of the GOx enzyme. GOx enzyme catalyzed and converted glucose to gluconolactone and $\mathrm{H}_{2} \mathrm{O}_{2}$. The presence of $\mathrm{H}_{2} \mathrm{O}_{2}$ converted 4-MPBA to 4-MPheOH on the surface of $\mathrm{SiO}_{2} @ \mathrm{Au} @ \mathrm{Au}$. The variation of SERS signal of 4-MPBA was observed and extrapolated to the concentration of glucose in solution (Figure 1). To prepare $\mathrm{SiO}_{2} @ \mathrm{Au} @ \mathrm{Ag}$, silica NPs $(\sim 150 \mathrm{~nm})$ were first functionalized by 3-aminopropyltriethoxysilane (APTS) to prepare 
aminated silica NPs. Simultaneously, colloidal Au NPs (3 nm) were synthesized by THPC and incubated with the aminated silica NPs by to prepare Au NPs seed embedded with $\mathrm{SiO}_{2}\left(\mathrm{SiO}_{2} @ \mathrm{Au}\right.$ seed NPs), according to the method reported by Pham et al. [37,38,42-44]. Subsequently, the Ag NPs on the surface of $\mathrm{SiO}_{2} @ \mathrm{Au}$ seed were grown by reducing a silver precursor $\left(\mathrm{AgNO}_{3}\right)$ in the presence of ascorbic acid (AA) and polyvinylpyrrolidone (PVP) [37]. The silver ions reduced by AA were selectively grown onto $\mathrm{SiO}_{2} @ \mathrm{Au}$ seed to generate the $\mathrm{SiO}_{2} @ \mathrm{Au} @ \mathrm{Ag}$ nanostructure. According to a previous study, 4-MPBA was used for specific binding of glucose with the boronic acid motif in 4-MPBA, leading to a significant increase in the absolute intensity of the SERS signal of 4-MPBA. So, we modified the surface of $\mathrm{SiO}_{2} @ \mathrm{Au} @ \mathrm{Ag}$ by 4-MBPA to generate $\mathrm{SiO}_{2} @ \mathrm{Au} @ \mathrm{Au} @ 4-\mathrm{MPBA}$ as a specific ligand for glucose. Subsequently, glucose was added in the reaction in the presence of glucose oxidase (GOx). GO catalyzed and converted glucose to glucolactone and hydrogen peroxide $\left(\mathrm{H}_{2} \mathrm{O}_{2}\right)$ in the reaction. $\mathrm{H}_{2} \mathrm{O}_{2}$ converts 4-MPBA to 4-mercaptophenol (4-MPhOH).

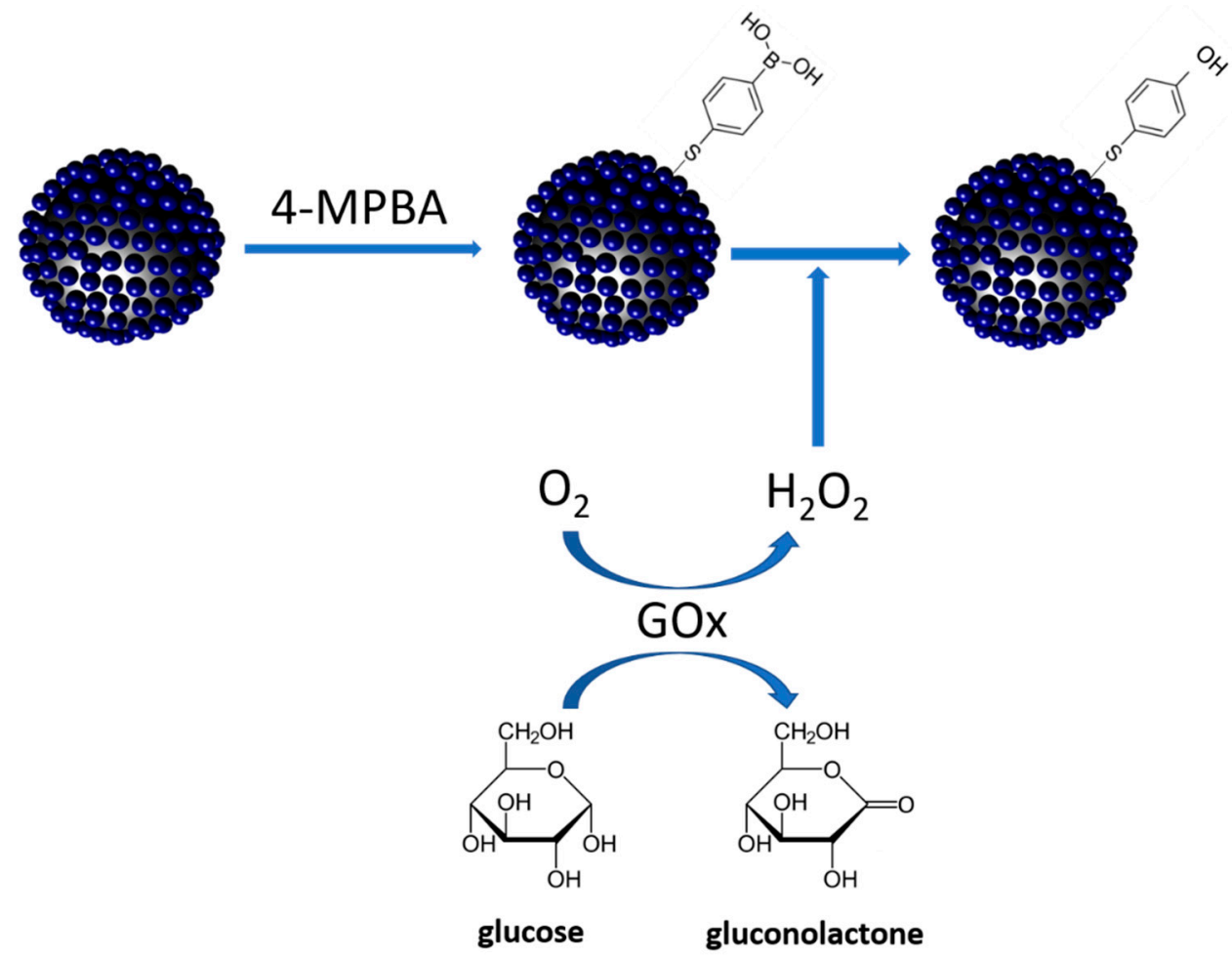

Figure 1. Typical illustration of glucose detection of 4-mercaptophenylboronic acid immobilizedgold-silver core-shell assembled silica nanostructure in the presence of glucose oxidase.

The characteristics of the $\mathrm{SiO}_{2} @ \mathrm{Au} @ \mathrm{Ag}$ NPs are first shown in Figure S1. The transmission electron microscopy (TEM) images of the $\mathrm{SiO}_{2} @ \mathrm{Au}$ and $\mathrm{SiO}_{2} @ \mathrm{Au} @ \mathrm{Ag} \mathrm{NPs}$ are shown in Figure S1a. Small-sized Au NPs (3 nm) were immobilized onto the surface of the $\mathrm{SiO}_{2}$ NPs when the colloidal Au NPs were incubated with the amine-functionalized silica NPs for $12 \mathrm{~h}$ at $25^{\circ} \mathrm{C}$ (Figure S1a-i). After the reduction of $\mathrm{AgNO}_{3}$ in the presence of PVP, the surface of the $\mathrm{SiO}_{2} @ \mathrm{Au}$ NPs contained many Ag NPs (Figure S1a-ii). The UV-Vis spectra of $\mathrm{SiO}_{2} @ \mathrm{Au}$ and $\mathrm{SiO}_{2} @ \mathrm{Au} @ \mathrm{Ag}$ were investigated, as shown in Figure $\mathrm{S} 1 \mathrm{~b}$. The suspension of the $\mathrm{SiO}_{2} @ \mathrm{Au}$ NPs exhibited the maximum peak at 500-520 nm (Figure S1b-i). A broad band was observed from 320-700 nm, with the maximum peak at $450 \mathrm{~nm}$, for the suspension of $\mathrm{SiO}_{2} @ \mathrm{Au} @ \mathrm{Ag}$ NPs (Figure S1b-ii). This indicated the generation of Ag shells, in addition to the creation of hot-spot structures, on the surfaces of the $\mathrm{SiO}_{2} @ \mathrm{Au}$ NPs, thus yielding a continuous spectrum of resonant multi-modes [37,38,42,43]. 


\subsection{Adsorption of 4-MPBA on the Surface of $\mathrm{SiO}_{2} @ A u @ A g$}

It is believed that 4-MBPA can selectively interact with glucose in solution, so the SERS-active $\mathrm{SiO}_{2} @ \mathrm{Au} @ \mathrm{Ag}$ were incubated with 4-MPBA solution for $1 \mathrm{~h}$ at $25^{\circ} \mathrm{C}$. Figure 2a showed the $\mathrm{SERS}$ bands of $\mathrm{SiO}_{2} @ \mathrm{Au} @ \mathrm{Ag} @ 4-\mathrm{MPBA}$ in ethanol solution. Compared to the $\mathrm{SiO}_{2} @ \mathrm{Au} @ \mathrm{Au}$ without 4-MPBA $(0 \mu \mathrm{M})$ and with $100 \mu \mathrm{M}$ 4-MPBA, we found that the $\mathrm{SiO}_{2} @ \mathrm{Au} @ \mathrm{Ag}$ in EtOH solution showed SERS bands at 432, 883, 1051, 1097, 1276, and $1455 \mathrm{~cm}^{-1}$, assigned to the SERS bands of the EtOH solution. At $100 \mu \mathrm{M} 4$-MPBA, clear and new bands were observed at 417, 473,1077,1170, 1484, and $1583 \mathrm{~cm}^{-1}$, indicating that 4-MPBA was successfully immobilized on the surface of $\mathrm{SiO}_{2} @ \mathrm{Au} @ \mathrm{Ag}$ [18]. The detailed SERS bands of $\mathrm{SiO}_{2} @ A u @ A g @ 4-M P B A$ can be seen in Table S1. The SERS intensity of $\mathrm{SiO}_{2} @ \mathrm{Au} @ \mathrm{Ag} @ 4-\mathrm{MBPA}$ was also examined in the presence of various concentrations of 4-MPBA from $0.1 \mu \mathrm{M}$ to $100 \mu \mathrm{M}$ in EtOH solution. The SERS signal of 4-MBPA increased from 0.1 to $10 \mu \mathrm{M}$ and achieved a saturation at $50 \mu \mathrm{M}$. In particular, the intensities of the Raman bands at $1583 \mathrm{~cm}^{-1}$ increased dramatically with 4-MPBA concentration (Figure $2 \mathrm{~b}$ ). Therefore, $50 \mu \mathrm{M}$ 4-MBPA was chosen for further study.
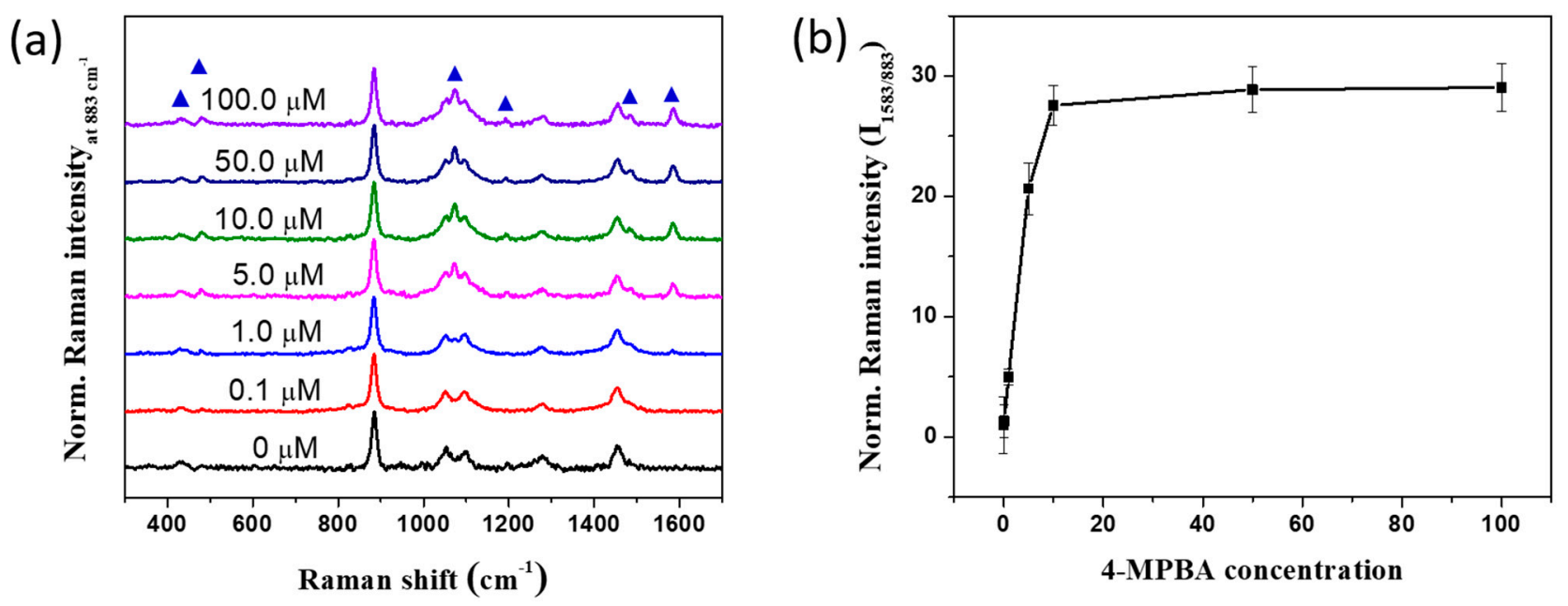

Figure 2. (a) SERS spectra and (b) normalized SERS intensity plot at $883 \mathrm{~cm}^{-1}$ of $\mathrm{SiO}_{2} @ \mathrm{Au} @ \mathrm{Ag} @ 4-\mathrm{MPBA}$ at various concentration from 0.1 to $100 \mu \mathrm{M}$ in ethanol solution.

However, the SERS signal of EtOH was too strong compared to the SERS signal of $\mathrm{SiO}_{2} @ \mathrm{Au} @ \mathrm{Ag} @ 4-\mathrm{MPBA}$, which can seriously affect the accuracy of analytical result. Therefore, we re-dispersed the $\mathrm{SiO}_{2} @ \mathrm{Au} @ \mathrm{Ag} @ 4-\mathrm{MPBA}$ in the PBST pH 7.0 (Figure 3a). Indeed, the SERS bands of 4-MPBA in PBST was clearly observed, compared to those in EtOH. Figure 3a showed that the typical SERS bands of 4-MBPA were dominated by bands at $417 \mathrm{~cm}^{-1}, 473 \mathrm{~cm}^{-1}, 824 \mathrm{~cm}^{-1}, 998 \mathrm{~cm}^{-1}, 1021 \mathrm{~cm}^{-1}, 1077 \mathrm{~cm}^{-1}, 1170 \mathrm{~cm}^{-1}$, $1484 \mathrm{~cm}^{-1}$, and $1583 \mathrm{~cm}^{-1}$. The SERS spectra at $998 \mathrm{~cm}^{-1}, 1021 \mathrm{~cm}^{-1}$, and $1077 \mathrm{~cm}^{-1}$, which are assigned to the $\mathrm{C}-\mathrm{C}$ in-plane breathing, $\mathrm{C}-\mathrm{H}$ in-plane breathing, and $\mathrm{C}-\mathrm{C}$ in-plane breathing and C-S stretching, respectively (Figure 3a, Table S1). The pair of intense bands at $1586 / 1573 \mathrm{~cm}^{-1}$ is ascribed to the original and $\mathrm{OH}^{-}$-associated forms of $\mathrm{C}-\mathrm{C}$ stretching. The SERS spectra at 824 and $417 \mathrm{~cm}^{-1}$ were assigned as the $C-C$ out-plane bending and the C-S stretching with weak intensities $[18,34,45,46]$.

\subsection{Behavior of $\mathrm{SiO}_{2} @ A u @ A g @ 4-M P B A$ in the Presence of Hydrogen Peroxide}

First, the $\mathrm{SiO}_{2} @ \mathrm{Au} @ \mathrm{Ag} @ 4-\mathrm{MPBA}$ were used as a SERS substrate for glucose detection in the range of 1 to $10 \mathrm{mM}$ (Figure S2a). According to the previous report, the boronic acid group of 4-MPBA specifically binds to glucose, leading to a significant increase in the absolute intensity of the SERS signal of 4-MPBA, which was ascribed to the orientation change and the charge transfer effect $[17,45]$. However, the SERS signal of $\mathrm{SiO}_{2} @ \mathrm{Au} @ \mathrm{Ag} @ 4-$ MPBA at $\mathrm{pH} 7.0$ in our study did not show any significantly difference in the range of 1 to 
$10 \mathrm{mM}$ glucose. Therefore, glucose oxidase enzyme was added to the glucose solution to convert glucose to gluconolactone and hydrogen peroxide to $\mathrm{SiO}_{2} @ \mathrm{Au} @ \mathrm{Ag} @ 4-\mathrm{MPBA}$ in our study. The behavior of $\mathrm{SiO}_{2} @ \mathrm{Au} @ \mathrm{Ag} @ 4-\mathrm{MPBA}$ in PBST pH 7.0 containing $1 \mathrm{mg} / \mathrm{mL}$ $\mathrm{H}_{2} \mathrm{O}_{2}$ was investigated and is shown in Figure 3a.

(a)

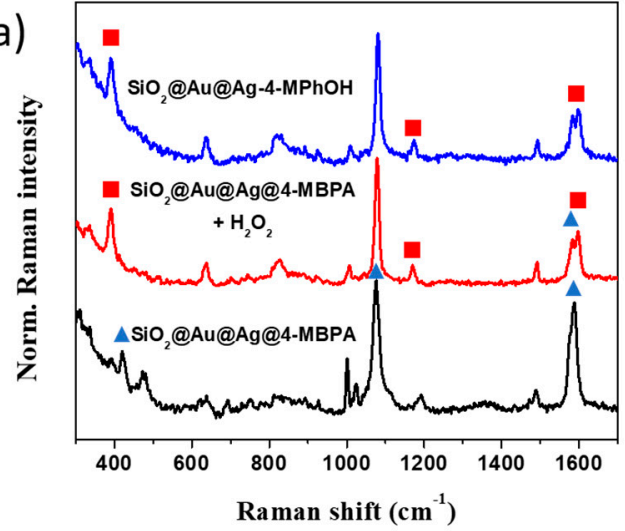

(b)

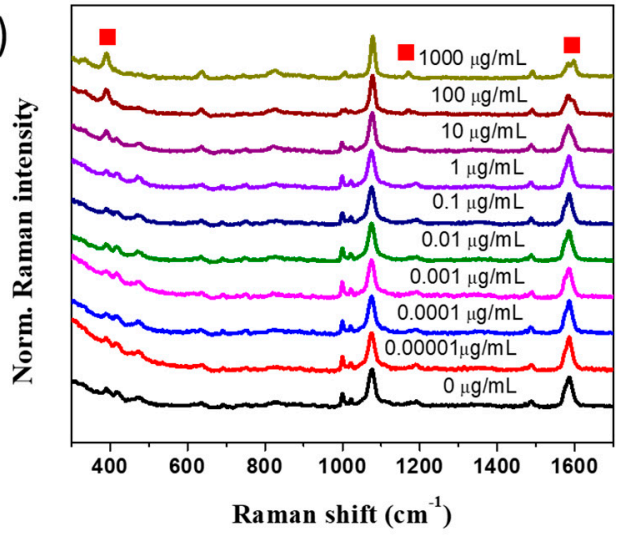

(c)

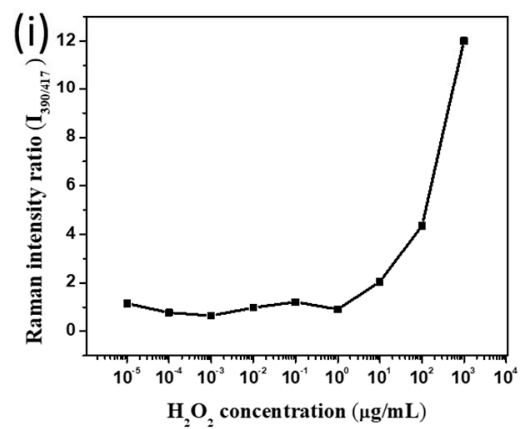

(ii)

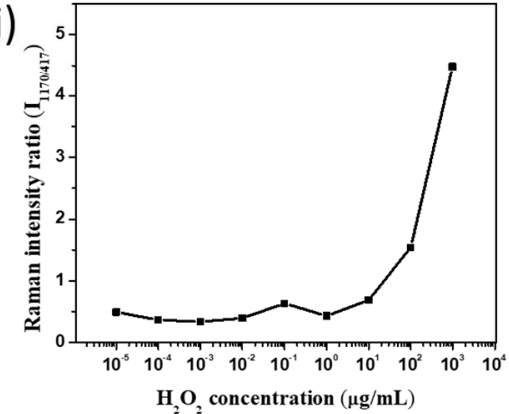

(iii)

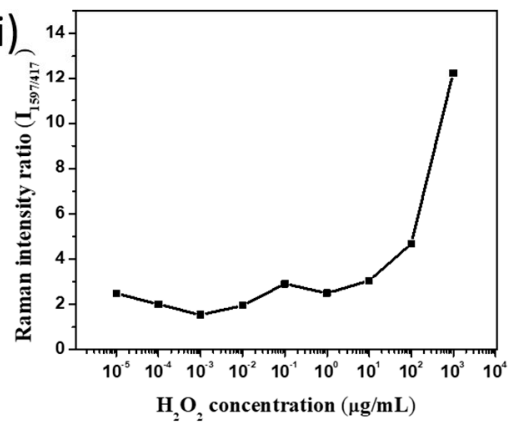

Figure 3. (a) SERS spectra and (b) SERS intensity of $\mathrm{SiO}_{2} @ \mathrm{Au} @ A g @ 4-M P B A$, and (c) SERS intensity ratio of $\mathrm{I}_{390 / 417}$, $\mathrm{I}_{1170 / 1077}, \mathrm{I}_{1597 / 1583}$ toward various concentration of $\mathrm{H}_{2} \mathrm{O}_{2}$ from $10 \mathrm{pg} / \mathrm{mL}$ to $1 \mathrm{mg} / \mathrm{mL}$ in PBST $\mathrm{pH}$ 7.0.

As mentioned above, we chose the SERS band of 4-MPBA at 417,1077, and $1583 \mathrm{~cm}^{-1}$ to investigate the variation of SERS band in the presence of $\mathrm{H}_{2} \mathrm{O}_{2}$. When $\mathrm{SiO}_{2} @ \mathrm{Au} @ \mathrm{Ag} @ 4$ MPBA was incubated with $\mathrm{H}_{2} \mathrm{O}_{2}$, the new bands could be observed clearly at $390 \mathrm{~cm}^{-1}$, $1170 \mathrm{~cm}^{-1}$, and $1597 \mathrm{~cm}^{-1}$. According to previous report, boronated molecules reacts selectively with $\mathrm{H}_{2} \mathrm{O}_{2}$ to convert to its corresponding phenol form, so 4-MPBA on the surface of $\mathrm{SiO}_{2} @ \mathrm{Au} @ \mathrm{Ag}$ can converted to 4-MPheOH or thiophenol $[34,46,47]$. Thus, we observed the SERS band of both 4-MPheOH and thiophenol in ethanol to compare with 4-MPBA in the presence of $\mathrm{H}_{2} \mathrm{O}_{2}$ (Figure S2b). The SERS bands of thiophenol was different from those of 4-PheOH, and 4-MPBA in the presence of $\mathrm{H}_{2} \mathrm{O}_{2}$ with dominant bands at $416 \mathrm{~cm}^{-1}, 996 \mathrm{~cm}^{-1}, 1018 \mathrm{~cm}^{-1}, 1069 \mathrm{~cm}^{-1}$, and $1570 \mathrm{~cm}^{-1}$. In contrast, the SERS bands of 4-MPBA in the presence of $\mathrm{H}_{2} \mathrm{O}_{2}$ was similar to those of 4-MPheOH with the typical bands at $390 \mathrm{~cm}^{-1}, 1170 \mathrm{~cm}^{-1}$, and the intense band at 1583/1597 $\mathrm{cm}^{-1}$ (Figure 3a). Based on these results, we concluded that 4-MPBA on the surface of $\mathrm{SiO}_{2} @ \mathrm{Au} @ \mathrm{Ag}$ was successfully converted to 4-MPheOH in PBST pH 7.0. The effect of $\mathrm{H}_{2} \mathrm{O}_{2}$ concentration in the range of $10 \mathrm{pg} / \mathrm{mL}$ to $1 \mathrm{mg} / \mathrm{mL}$ on the SERS signal of 4-MPBA was also observed in Figure $3 \mathrm{~b}$. The bands at $390 \mathrm{~cm}^{-1}, 1170 \mathrm{~cm}^{-1}$, and $1597 \mathrm{~cm}^{-1}$ increased while the bands at $417 \mathrm{~cm}^{-1}$ and $1583 \mathrm{~cm}^{-1}$ decreased dramatically with the $\mathrm{H}_{2} \mathrm{O}_{2}$ concentration. The SERS intensity at $1077 \mathrm{~cm}^{-1}$ was slightly changed. We used the SERS bands of 4-MPBA at $417 \mathrm{~cm}^{-1}$, $1077 \mathrm{~cm}^{-1}$, and $1583 \mathrm{~cm}^{-1}$ as intrinsic internal standards to robust quantitative detection of $\mathrm{H}_{2} \mathrm{O}_{2}$ in our study. The results are shown in Figure $3 \mathrm{c}$ and Figure S3. Indeed, the increase of $\mathrm{H}_{2} \mathrm{O}_{2}$ concentration led to increases of SERS ratio of $\mathrm{I}_{390 / 417}, \mathrm{I}_{390 / 1077}, \mathrm{I}_{390 / 1583}, \mathrm{I}_{1170 / 417}$, $\mathrm{I}_{1170 / 1077}, \mathrm{I}_{1170 / 1583}, \mathrm{I}_{1597 / 417}, \mathrm{I}_{1597 / 1077}$, and $\mathrm{I}_{1597 / 1583}$ (Figure S3). The dramatic increase in SERS ratio was observed in the range of $1 \mu \mathrm{g} / \mathrm{mL}$ to $1000 \mu \mathrm{g} / \mathrm{mL}$ of $\mathrm{H}_{2} \mathrm{O}_{2}$. The detection 
limit of $\mathrm{H}_{2} \mathrm{O}_{2}$ based on the SERS ration of $\mathrm{I}_{1583 / 1597}$ was calculated to be $0.31 \mu \mathrm{g} / \mathrm{mL}(3 \sigma / \mathrm{k}$, where $\sigma$ is the standard deviation of the blank and $\mathrm{k}$ is the slope of the calibration slope).

Next, the effect of experimental conditions for glucose detection on the SERS signal of $\mathrm{SiO}_{2} @ \mathrm{Au} @ \mathrm{Ag} @ 4-\mathrm{MPBA}$ in the presence of GOx were examined and optimized in Figure 4 and Figures S4-S7.
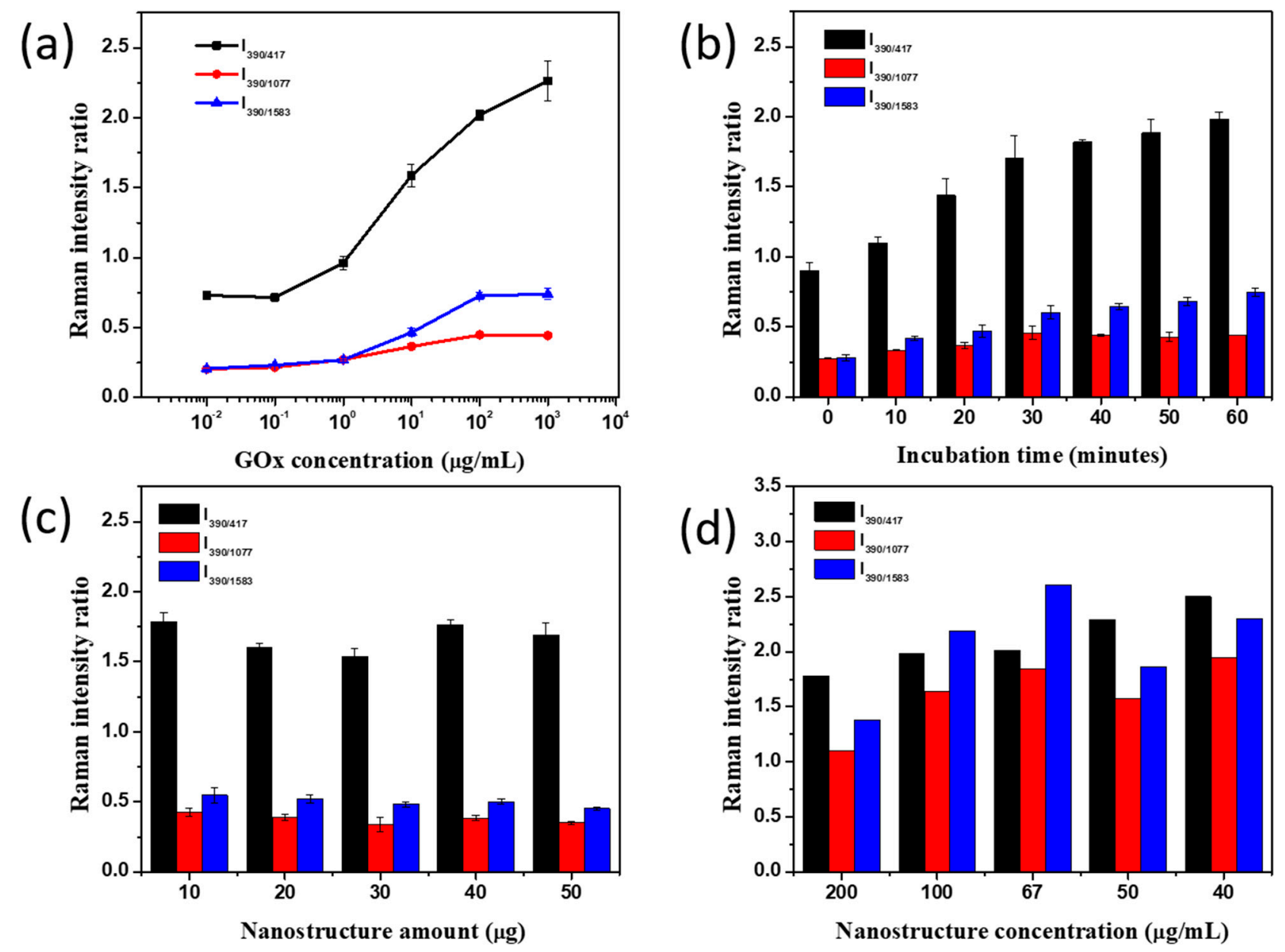

Figure 4. Optimization of glucose detection by $\mathrm{SiO}_{2} @ \mathrm{Au} @ \mathrm{Au} @ 4-\mathrm{MPBA}$ in all-in-one technique, (a) glucose oxidase concentration, (b) incubation time, (c) $\mathrm{SiO}_{2} @ \mathrm{Au} @ \mathrm{Ag} @ 4-\mathrm{MBA}$ amount, and (d) dilution of $\mathrm{SiO}_{2} @ \mathrm{Au} @ \mathrm{Ag}$ for Raman measurement in PBST at $\mathrm{I}_{390 / 417}, \mathrm{I}_{390 / 1077}, \mathrm{I}_{390 / 1583}$.

To reduce the detection time of glucose, we attempted to combine the enzyme reaction and conversion of 4-MPBA to 4-MPheOH into one step, which is termed the "all-in-one" technique. We also conducted the glucose detection in two separate steps: The enzyme reaction followed by the conversion of 4-MPBA to 4-MPheOH, which is termed the "stepby-step" technique. For both techniques, the glucose concentration was fixed at $5 \mathrm{mM}$ using $20 \mu \mathrm{g} \mathrm{SiO}_{2} @ \mathrm{Au} @ \mathrm{Ag} @ 4-\mathrm{MPBA}$ for 30 min while the GOx concentration was varied in the range of $10^{-2}-10^{3} \mu \mathrm{g} / \mathrm{mL}$. The results showed that the SERS signal of the $\mathrm{SiO}_{2} @ \mathrm{Au} @ \mathrm{Ag} @ 4-$ MPBA at $5 \mathrm{mM}$ glucose and various concentration of GOx in both the "step-by-step" and "all-in-one" techniques were quite similar (Figure S4). However, the SERS signal of $\mathrm{SiO}_{2} @ \mathrm{Au} @ \mathrm{Ag} @ 4-\mathrm{MPBA}$ in the "step-by-step" reached saturation earlier than that in the "all-in-one". As a result, its dynamic linear range was narrower than that of "all-in-one". Figure 4a showed that in general the SERS signal at $\mathrm{I}_{390 / 1077}$, and $\mathrm{I}_{390 / 1583}$ increased with the GOx concentration in the range of 0.1 to $100 \mu \mathrm{g} / \mathrm{mL}$ and achieved the saturation at $100 \mu \mathrm{g} / \mathrm{mL}$ GOx, while the SERS ratio at $\mathrm{I}_{390 / 417}$ increased with the GOx concentration in the range of 1 to $1000 \mu \mathrm{g} / \mathrm{mL}$. Thus, $100 \mu \mathrm{g} / \mathrm{mL}$ GOx was utilized for further study. 
The incubation time of glucose detection by the $\mathrm{SiO}_{2} @ \mathrm{Au} @ \mathrm{Ag} @ 4-\mathrm{MPBA}$ was also performed in Figure $4 \mathrm{~b}$ and Figure S5. The SERS ratio at $\mathrm{I}_{390 / 1077}$ was saturated at $30 \mathrm{~min}$, and another SERS ratio of the $\mathrm{SiO}_{2} @ \mathrm{Au} @ \mathrm{Ag} @ 4-\mathrm{MPBA}$ increased with incubation time until 1h. The gradual increase in the SERS signal of $\mathrm{SiO}_{2} @ \mathrm{Au} @ \mathrm{Ag} @ 4-\mathrm{MPBA}$ in the presence of GOx indicated that the enzyme reaction and conversion of 4-MPBA to 4-MPheOH took place simultaneously for $1 \mathrm{~h}$.

In addition, the effect of $\mathrm{SiO}_{2} @ \mathrm{Au} @ \mathrm{Ag} @ 4-\mathrm{MPBA}$ core-shell amount was observed in the range of 10 to $50 \mu \mathrm{g}$. The results can be seen in Figure $4 \mathrm{c}$ and Figure S6. It is well known that SERS signal depends on the Raman reporter of nanomaterials [39]. Therefore, when a greater amount of $\mathrm{SiO}_{2} @ \mathrm{Au} @ \mathrm{Ag} @ 4-\mathrm{MPBA}$ was added, more 4-MPBA were available on the surface of $\mathrm{SiO}_{2} @ \mathrm{Au} @ \mathrm{Ag}$, generating numerous detection sites for glucose. However, the SERS signals of the $\mathrm{SiO}_{2} @ \mathrm{Au} @ \mathrm{Ag} @ 4-\mathrm{MPBA}$ at various core-shell quantities were insignificantly different in our study, indicating that quantities of 4-MPBA molecules of $\mathrm{SiO}_{2} @ \mathrm{Au} @ \mathrm{Ag}$ at $10 \mu \mathrm{g}$ were enough to react with all $\mathrm{H}_{2} \mathrm{O}_{2}$ generated by $5 \mathrm{mM}$ glucose in the enzyme reaction. However, to ensure that the $\mathrm{SiO}_{2} @ \mathrm{Au} @ \mathrm{Ag} @ 4-\mathrm{MPBA}$ is sufficient to convert $\mathrm{H}_{2} \mathrm{O}_{2}$ generated by higher glucose concentration in diabetes, we decided to use $20 \mu \mathrm{g} \mathrm{SiO}_{2} @ \mathrm{Au} @ \mathrm{Ag} @ 4-\mathrm{MPBA}$ for further study.

For Raman measurement, the concentration of SERS substrate is one of the most important factors affecting the SERS signal $[39,41,44]$. Figure 4d and Figure S7 showed the effect of $\mathrm{SiO}_{2} @ \mathrm{Au} @ \mathrm{Ag} @ 4-\mathrm{MPBA}$ concentration after glucose incubation in the presence of GOx on the SERS signal of 4-MPBA. In the absence of glucose, the SERS signal of $\mathrm{SiO}_{2} @ \mathrm{Au} @ \mathrm{Ag} @ 4-\mathrm{MPBA}$ suspension significantly decreased when $\mathrm{SiO}_{2} @ \mathrm{Au} @ \mathrm{Ag} @ 4$ MPBA concentration decreased from $200 \mu \mathrm{g} / \mathrm{mL}$ to $100 \mu \mathrm{g} / \mathrm{mL}$ and the SERS signals were almost unchanged after $100 \mu \mathrm{g} / \mathrm{mL} \mathrm{SiO}_{2} @ \mathrm{Au} @ \mathrm{Ag} @ 4-M P B A$. Meanwhile, the SERS signals of $\mathrm{SiO}_{2} @ \mathrm{Au} @ \mathrm{Ag} @ 4-\mathrm{MPBA}$ in the presence of $5 \mathrm{mM}$ glucose increased slightly when $\mathrm{SiO}_{2} @ \mathrm{Au} @ \mathrm{Ag} @ 4-\mathrm{MPBA}$ decreased to $67 \mu \mathrm{g} / \mathrm{mL}$. After subtracting background signal, the SERS signal achieved the highest value at $67 \mu \mathrm{g} / \mathrm{mL}$. For concentrations lower than $50 \mu \mathrm{g} / \mathrm{mL}$, the SERS signal of the glucose-incubated $\mathrm{SiO}_{2} @ \mathrm{Au} @ \mathrm{Ag} @ 4-\mathrm{MPBA}$ suspension decreased sharply owing to the low diffraction of the suspension.

Based on the above-mentioned results, the highest signal of glucose detection by the $\mathrm{SiO}_{2} @ \mathrm{Au} @ \mathrm{Ag} @ 4-\mathrm{MPBA}$ in the presence of GOx was achieved at $100 \mu \mathrm{g} / \mathrm{mL}$ GOx with 1-h incubation time using $20 \mu \mathrm{g} \mathrm{SiO}_{2} @ \mathrm{Au} @ \mathrm{Ag} @ 4-\mathrm{MPBA}$ and Raman measurement at $67 \mu \mathrm{g} / \mathrm{mL} \mathrm{SiO}{ }_{2} @ \mathrm{Au} @ \mathrm{Ag} @ 4-\mathrm{MPBA}$.

After optimizing the detection conditions, the SERS spectra of the $\mathrm{SiO}_{2} @ \mathrm{Au} @ \mathrm{Ag} @ 4$ MPBA suspensions with various glucose concentrations were obtained. Figure 5 described the changes in SERS signal of $\mathrm{SiO}_{2} @ \mathrm{Au} @ \mathrm{Ag} @ 4-\mathrm{MPBA}$ after reacting with different concentrations of in glucose the range of 0.5 to $8.0 \mathrm{mM}$ with and without $100 \mu \mathrm{g} / \mathrm{mL} \mathrm{GOx}$. The SERS signals of the nanomaterial suspensions at $\mathrm{I}_{390 / 417}, \mathrm{I}_{390 / 1077}, \mathrm{I}_{390 / 1583}, \mathrm{I}_{1170 / 417}$, $\mathrm{I}_{1170 / 1077, \mathrm{I} 1170 / 1583}, \mathrm{I}_{1597 / 417}, \mathrm{I}_{1597 / 1077}$, and $\mathrm{I}_{1597 / 1583}$ increased sharply when the glucose concentration was increased from $0.5 \mathrm{mM}$ to $8.0 \mathrm{mM}$ (Figure S8). This implied that $\mathrm{H}_{2} \mathrm{O}_{2}$ was produced from GOx in the suspensions by the GOx, and that $\mathrm{H}_{2} \mathrm{O}_{2}$ was able to convert 4-MPBA to 4-MPheOH on the surface of $\mathrm{SiO}_{2} @ \mathrm{Au} @ \mathrm{Ag}$. When the concentration of glucose increased higher than $6.0 \mathrm{mM}$, the SERS peak reached saturation. This result was due to complete conversion of 4-MPBA to 4-MPheOH on the surface of $\mathrm{SiO}_{2} @ \mathrm{Au} @ \mathrm{Ag} @ 4-\mathrm{MPBA}$. Meanwhile, the SERS signal of $\mathrm{SiO}_{2} @ \mathrm{Au} @ \mathrm{Ag} @ 4-\mathrm{MPBA}$ in glucose without GOx remained unchanged, indicating that the increase of glucose in the solution did not significantly affect the SERS of 4-MPBA on the surface of $\mathrm{SiO}_{2} @ \mathrm{Au} @ \mathrm{Ag}$ as mentioned in Figure 2. Therefore, we concluded that the SERS signal of $\mathrm{SiO}_{2} @ \mathrm{Au} @ \mathrm{Ag} @ 4-\mathrm{MPBA}$ in the glucose solution in the presence of GOx was the result of the combination of the GOx reaction and the conversion of 4-MPBA to 4-MPheOH on the surface of $\mathrm{SiO}_{2} @ \mathrm{Au} @ \mathrm{Ag}$.

A linear curve-fitting procedure was utilized for calibration. A significant relationship between the SERS signal ratio and the glucose concentration was found in the experimental data points ranging from 1.0 to $8.0 \mathrm{mM}$ (calibration curve: $\mathrm{y}=0.159 \mathrm{x}+0.707$, where $\mathrm{x}$ is glucose concentration, $\mathrm{y}$ is the SERS ration, and $\left.\mathrm{R}^{2}=0.99\right)$. The theoretical LOD was 
$0.15 \mathrm{mM}$, estimated by the 3sblank criterion. Our result demonstrates that our material can be utilized for glucose detection for diagnosis.

(a)

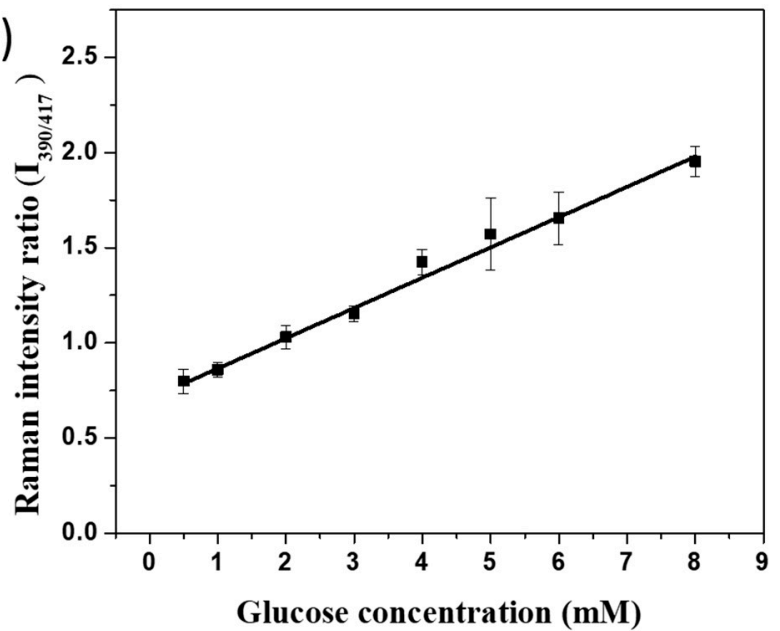

(b)

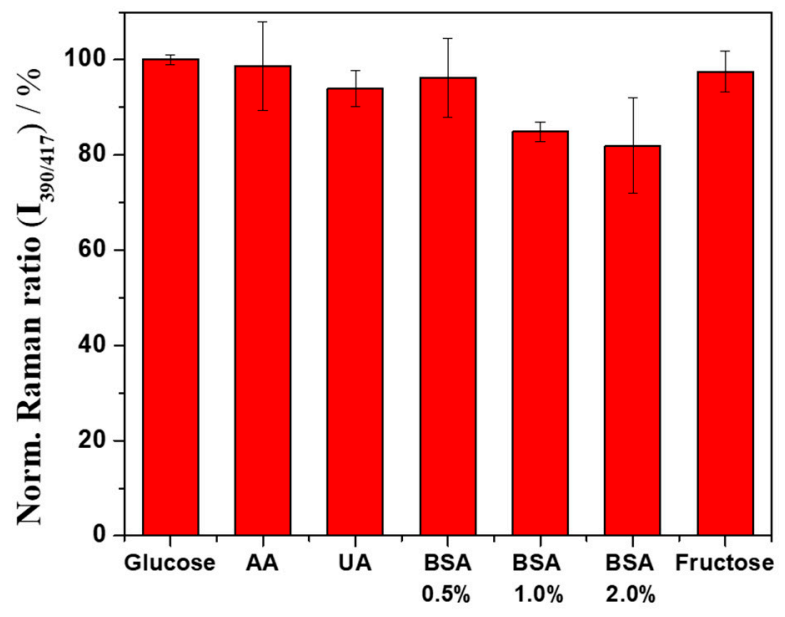

Figure 5. (a) SERS signal plot of $\mathrm{SiO}_{2} @ \mathrm{Au} @ A u @ 4-\mathrm{MPBA}$ at various glucose concentrations and $(\mathbf{b})$ the effect of interferences on the SERS signal of $\mathrm{SiO}_{2} @ \mathrm{Au} @ \mathrm{Ag} @ 4-\mathrm{MPBA}$ in $5 \mathrm{mM}$ glucose and $50 \mu \mathrm{M} \mathrm{AA}, 40 \mu \mathrm{M} \mathrm{UA}, 0.5 \% \mathrm{BSA}, 1 \% \mathrm{BSA}, 2 \% \mathrm{BSA}$, and $5 \mu \mathrm{M}$ fructose by $\mathrm{SiO}_{2} @ \mathrm{Au} @ \mathrm{Au} @ 4-\mathrm{MPBA}$ in PBST at SERS ratio of 390 and 417. The optimized condition is $20 \mu \mathrm{g}$

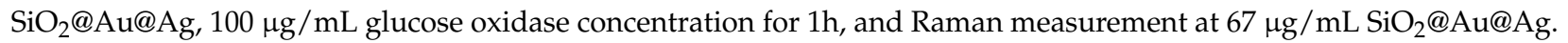

The interference behavior is an important factor for glucose detection since easily oxidizable species, such as ascorbic acid (AA), uric acid (UA), and bovine serum albumin (BSA), at various concentrations and fructose co-exist with glucose in blood samples [48-50]. Figure $5 \mathrm{~b}$ depicted the evaluation of the selectivity of the $\mathrm{SiO}_{2} @ \mathrm{Au} @ \mathrm{Ag} @ 4-$ MPBA as a SERS substrate for glucose detection at $\mathrm{I}_{390 / 417}$ in the presence of interfering species including $50 \mu \mathrm{M}$ AA, $40 \mu \mathrm{M} \mathrm{UA}, 0.5 \% \mathrm{BSA}, 1 \% \mathrm{BSA}, 2 \% \mathrm{BSA}$, and $5 \mu \mathrm{M}$ fructose were evaluated. Additionally, the SERS ration response of the $\mathrm{SiO}_{2} @ \mathrm{Au} @ \mathrm{Ag} @ 4-\mathrm{MPBA}$ in $5 \mathrm{mM}$ glucose was examined as a reference, and the response SERS ratios at $\mathrm{I}_{390 / 417}$, $\mathrm{I}_{390 / 1077}, \mathrm{I}_{390 / 1583}, \mathrm{I}_{1170 / 417}, \mathrm{I}_{1170 / 1077}, \mathrm{I}_{1170 / 1583}, \mathrm{I}_{1597 / 417}, \mathrm{I}_{1597 / 1077}$, and $\mathrm{I}_{1597 / 1583}$ in $5 \mathrm{mM}$ glucose in the presence of interferences were simultaneously observed in Figure S9. In the presence of $50 \mu \mathrm{M}$ AA, the SERS ratio of $\mathrm{SiO}_{2} @ \mathrm{Au} @ \mathrm{Ag} @ 4-\mathrm{MPBA}$ at $\mathrm{I}_{390 / 417}$ decreased $2 \%$ to $98 \%$, while in the presence of $40 \mu \mathrm{M} \mathrm{UA}$, it decreased to $95 \%$ compared to the SERS ratio of $5 \mathrm{mM}$ glucose. The presence of $0.5 \%$ BSA caused an insignificant decrease in the SERS ratio at $\mathrm{I}_{390 / 417}$ to $96 \%$. However the SERS ratio at $\mathrm{I}_{390 / 417}$ in the presence of $1 \%$ BSA or $2 \%$ BSA showed a significant decrease to 86 and $82 \%$, respectively, because of the adsorption of BSA on the surface of $\mathrm{SiO}_{2} @ \mathrm{Au} @ \mathrm{Ag} @ 4-\mathrm{MPBA}$ [51]. The SERS ratio at $\mathrm{I}_{390 / 417}$ of $5 \mathrm{mM}$ glucose in the presence of $5 \mu \mathrm{M}$ fructose decreased slightly to $98 \%$. It meant that the detection of glucose by $\mathrm{SiO}_{2} @ \mathrm{Au} @ \mathrm{Ag} @ 4-\mathrm{MPBA}$ was highly selective. Thereby, the combination of $\mathrm{GOx}$ and $\mathrm{SiO}_{2} @ \mathrm{Au} @ \mathrm{Ag} @ 4-\mathrm{MPBA}$ exhibited excellent selectivity for glucose detection in the presence of interfering species, $50 \mu \mathrm{M} \mathrm{AA}, 40 \mu \mathrm{M}$ UA, $0.5 \% \mathrm{BSA}$, and $5 \mu \mathrm{M}$ fructose with negligible interference to the SERS signal of glucose.

The long-term storage of the $\mathrm{SiO}_{2} @ \mathrm{Au} @ \mathrm{Ag} @ 4$-MPBA was examined in Figure S10. First, $200 \mu / \mathrm{mL} \mathrm{SiO}_{2} @ \mathrm{Au} @ A g @ 4-\mathrm{MPBA}$ was synthesized, re-dispersed in EtOH, and stored at $4{ }^{\circ} \mathrm{C}$ for one week. The SERS signal of 4-MPBA was measured every day and the SERS signal at $1583 \mathrm{~cm}^{-1}$ was monitored. As showed in Figure S10, the SERS signal was not decreased until seven days, indicating that the surface of $\mathrm{SiO}_{2} @ \mathrm{Au} @ \mathrm{Ag}$ was not oxidized during storage in $\mathrm{EtOH}$ at $4{ }^{\circ} \mathrm{C}$. However, the SERS signal slightly increased after four days, which might be from the partly aggregation of $\mathrm{SiO}_{2} @ \mathrm{Au} @ \mathrm{Ag}$. 


\section{Conclusions}

We have developed a new SERS-based boronated nanoprobe of the $\mathrm{SiO}_{2} @ \mathrm{Au} @ \mathrm{Ag} @ 4-$ MPBA for quantitative, selective detection of glucose in neutral condition. This work confirmed that 4-MPBA was converted to 4-MPhOH in the presence of $\mathrm{H}_{2} \mathrm{O}_{2}$. Moreover, it provided a new calibration curve to evaluate $\mathrm{H}_{2} \mathrm{O}_{2}$ species in the range of 1.0 to $1000 \mu \mathrm{g} / \mathrm{mL}$ with LOD as low as $0.3 \mu \mathrm{g} / \mathrm{mL}$. Moreover, the $\mathrm{SiO}_{2} @ \mathrm{Au} @ \mathrm{Ag} @ 4-\mathrm{MPBA}$ for glucose detection in the presence of GOx were optimized at $100 \mu \mathrm{g} / \mathrm{mL}$ GOx, $100 \mu \mathrm{g} / \mathrm{mL}$ GOx with 1-h incubation time using $20 \mu \mathrm{g} / \mathrm{mL} \mathrm{SiO}_{2} @ \mathrm{Au} @ A g @ 4-M P B A$ and measuring Raman signal at $67 \mu \mathrm{g} / \mathrm{mL} \mathrm{SiO}_{2} @ \mathrm{Au} @ \mathrm{Ag}$. At the optimized condition, the calibration curve for selective glucose detection in the range of 0.5 to $8.0 \mathrm{mM}$ was successfully developed with an LOD of $0.15 \mathrm{mM}$. The combination of GOx and our nanostructure also illustrated that our SERS probe can be coupled with other enzymes to greatly expand its applicability to biologically active targets.

Supplementary Materials: The following are available online at https://www.mdpi.com/article/ 10.3390/nano11040948/s1, Figure S1. (a) TEM images and (b) UV-Vis spectra of (i) $\mathrm{SiO}_{2} @ \mathrm{Au}$

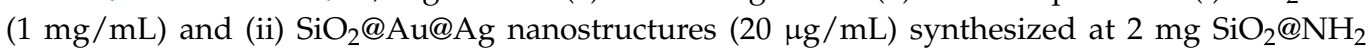
and $300 \mathrm{mM} \mathrm{Ag}^{+}$concentration. Figure S2. (a) SERS spectra of $\mathrm{SiO}_{2} @ \mathrm{Au} @ \mathrm{Ag} @ 4-\mathrm{MPBA}$ in PBST containing difference concentration of glucose (0-10 mM). (b) SERS spectra of $\mathrm{SiO}_{2} @ \mathrm{Au} @ \mathrm{Au}$ in ethanol in the presence of $50 \mu \mathrm{M}$ 4-mercaptophenylboronic acid, $50 \mu \mathrm{M}$ 4-mercaptophenylboronic acid $+1000 \mu \mathrm{g} / \mathrm{mL} \mathrm{H}_{2} \mathrm{O}_{2}, 1 \mathrm{mM}$ 4-mercaptophenol, $1 \mathrm{mM}$ thiophenol; Figure S3. Normalized Raman intensity ratio of $20 \mu \mathrm{g} \mathrm{SiO} \mathrm{S}_{2} @ \mathrm{Au} @ \mathrm{Ag} @ 4-\mathrm{MPBA}$ in PBST containing various concentration of $\mathrm{H}_{2} \mathrm{O}_{2}$ in the range of $10^{-6}-10^{3} \mu \mathrm{g} / \mathrm{mL}$ at (a) $390 / 417$; (b) 390/1077; (c) 390/1583; (d) $1170 / 417$; (e) 1170/1077; (f) 1170/1583; (g) 1597/417; (h) 1597/1077 and (f) 1597/1583; Figure S4. Normalized Raman intensity ratio of $20 \mu \mathrm{g} \mathrm{SiO} \mathrm{S}_{2} @ \mathrm{Au} @ \mathrm{Ag} @ 4-\mathrm{MPBA}$ in PBST containing $5 \mathrm{mM}$ glucose and difference concentration of glucose oxidase in the range of $10^{-2}-10^{3} \mu \mathrm{g} / \mathrm{mL}$ at (a) $390 / 417$; (b) 390/1077; (c) 390/1583; (d) 1170/417; (e) 1170/1077; (f) 1170/1583; (g) 1597/417; (h) 1597/1077 and

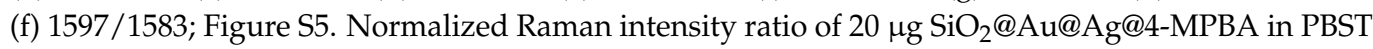
containing $5 \mathrm{mM}$ glucose and $100 \mu \mathrm{g} / \mathrm{mL}$ glucose oxidase at different incubation time at (a) 390/417; (b) 390/1077; (c) 390/1583; (d) 1170/417; (e) 1170/1077; (f) 1170/1583; (g) 1597/417; (h) 1597/1077 and (f) 1597/1583; Figure S6. Normalized Raman intensity ratio of $\mathrm{SiO}_{2} @ A u @ A g @ 4-M P B A ~ u s-$ ing different amount of $\mathrm{SiO}_{2} @ \mathrm{Au} @ \mathrm{Ag}(10-50 \mu \mathrm{g})$ in PBST containing $5 \mathrm{mM}$ glucose, $100 \mu \mathrm{g} / \mathrm{mL}$ glucose oxidase for $1 \mathrm{~h}$ at (a) 390/417; (b) 390/1077; (c) 390/1583; (d) 1170/417; (e) 1170/1077; (f) 1170/1583; (g) 1597/417; (h) 1597/1077 and (f) 1597/1583; Figure S7. Normalized Raman intensity ratio of $20 \mu \mathrm{g} \mathrm{SiO}{ }_{2} @ \mathrm{Au} @ \mathrm{Ag} @ 4-\mathrm{MPBA}$ in PBST containing $5 \mathrm{mM}$ glucose, $100 \mu \mathrm{g} / \mathrm{mL}$ glucose oxidase for $1 \mathrm{~h}$ and measure at different concentration of $\mathrm{SiO}_{2} @ \mathrm{Au} @ \mathrm{Ag}$ at (a) 390/417; (b) 390/1077; (c) 390/1583; (d) 1170/417; (e) 1170/1077; (f) 1170/1583; (g) 1597/417; (h) 1597/1077 and (f) 1597/1583; Figure S8. Glucose detection by $\mathrm{SiO}_{2} @ \mathrm{Au} @ A u @ 4-M P B A$ at optimized condition of $20 \mu \mathrm{g} \mathrm{SiO} \mathrm{O}_{2} @ \mathrm{Au} @ \mathrm{Ag}, 100 \mu \mathrm{g} / \mathrm{mL}$ glucose oxidase concentration for $1 \mathrm{~h}$ and Raman measurement at $67 \mu \mathrm{g} / \mathrm{mL} \mathrm{SiO}_{2} @ \mathrm{Au} @ \mathrm{Ag}$ in PBST at (a) 390/417; (b) 390/1077; (c) 390/1583; (d) 1170/417; (e) 1170/1077; (f) 1170/1583; (g) 1597/417; (h) 1597/1077 and (f) 1597/1583; Figure S9. Effect of interferences on SERS signal of $\mathrm{SiO}_{2} @ \mathrm{Au} @ \mathrm{Ag} @ 4-\mathrm{MPBA}$ in $5 \mathrm{mM}$ glucose by $\mathrm{SiO}_{2} @ \mathrm{Au} @ \mathrm{Au} @ 4-\mathrm{MPBA}$ at optimized condition of $20 \mu \mathrm{g} \mathrm{SiO} \mathrm{S}_{2} \mathrm{Au} @ \mathrm{Ag}, 100 \mu \mathrm{g} / \mathrm{mL}$ glucose oxidase concentration for $1 \mathrm{~h}$ and Raman measurement at $67 \mu \mathrm{g} / \mathrm{mL} \mathrm{SiO}_{2} @ \mathrm{Au} @ \mathrm{Ag}$ in PBST at (a) 390/417; (b) 390/1077; (c) 390/1583; (d) 1170/417; (e) 1170/1077; (f) 1170/1583; (g) 1597/417; (h) 1597/1077 and (f) 1597/1583. Figure S10. Long-term storage of $200 \mu \mathrm{g} / \mathrm{mL} \mathrm{SiO}{ }_{2} @ A u @ A g @ 4-M P B A$ at $4{ }^{\circ} \mathrm{C}$ in ethanol solution. Table S1. Raman frequencies and assignments of 4-MPBA and 4-MPheOH in EtOH and PBST

Author Contributions: Conceptualization, X.-H.P. and B.-H.J.; methodology, B.S. and X.-H.P.; investigation, B.S. and Y.-H.K.; formal analysis, K.-H.H. and E.H.; software, S.H.L.; writing—original draft preparation, X.-H.P.; writing—review and editing, J.K. and B.-H.J.; supervisor, B.-H.J. All authors have read and agreed to the published version of the manuscript.

Funding: This work was supported by the KU Research Professor Program of Konkuk University and funded by the Ministry of Science and ITC (NRF-2019R1G1A1006488) and by Ministry of Education (NRF-2018R1D1A1B07045708). 
Data Availability Statement: Data of the study is included in the main text and/or the supplementary materials.

Acknowledgments: The authors are grateful for the financial support from the NRF of Korea. Further, the author thanks the financial support by Konkuk University.

Conflicts of Interest: The authors declare no conflict of interest.

\section{References}

1. Rahman, M.M.; Ahammad, A.J.S.; Jin, J.-H.; Ahn, S.J.; Lee, J.-J. A Comprehensive Review of Glucose Biosensors Based on Nanostructured Metal-Oxides. Sensors 2010, 10, 4855-4886. [CrossRef] [PubMed]

2. Reach, G.; Wilson, G.S. Can Continuous Glucose Monitoring Be Used for the Treatment of Diabetes. Anal. Chem. 1992, 64, 381A-386A. [CrossRef] [PubMed]

3. Dutta, A.K.; Maji, S.K.; Biswas, P.; Adhikary, B. New Peroxidase-substrate 3,5-di-tert-butylcatechol for Colorimetric Determination of Blood Glucose in Presence of Prussian Blue-modified Iron Oxide Nanoparticles. Sens. Actuator B Chem. 2013, 177, 676-683. [CrossRef]

4. Chen, H.; Fang, A.; He, L.; Zhang, Y.; Yao, S. Sensitive Fluorescent Detection of $\mathrm{H}_{2} \mathrm{O}_{2}$ and Glucose in Human Serum Based on Inner Filter Effect of Squaric Acid-iron(III) on the Fluorescence of Upconversion Nanoparticle. Talanta 2017, 164, 580-587. [CrossRef] [PubMed]

5. Sato, T.; Katayama, K.; Arai, T.; Sako, T.; Tazaki, H. Simultaneous Determination of Serum Mannose and Glucose Concentrations in Dog Serum Using High Performance Liquid Chromatography. Res. Vet. Sci. 2008, 84, 26-29. [CrossRef]

6. Musto, C.J.; Suslick, K.S. Differential Sensing of Sugars by Colorimetric Arrays. Curr. Opin. Chem. Biol. 2010, 14, 758-766. [CrossRef]

7. Deng, J.; Yu, P.; Wang, Y.; Yang, L.; Mao, L. Visualization and Quantification of Neurochemicals with Gold Nanoparticles: Opportunities and Challenges. Adv. Mater. 2014, 26, 6933-6943. [CrossRef]

8. Radhakumary, C.; Sreenivasan, K. Naked Eye Detection of Glucose in Urine Using Glucose Oxidase Immobilized Gold Nanoparticles. Anal. Chem. 2011, 83, 2829-2833. [CrossRef]

9. Jiang, Y.; Zhao, H.; Lin, Y.; Zhu, N.; Ma, Y.; Mao, L. Colorimetric Detection of Glucose in Rat Brain Using Gold Nanoparticles. Angew. Chem. Int. Ed. 2010, 49, 4800-4804. [CrossRef] [PubMed]

10. Li, C.; Hu, J.; Liu, T.; Liu, S. Stimuli-Triggered Off/On Switchable Complexation between a Novel Type of Charge-Generation Polymer (CGP) and Gold Nanoparticles for the Sensitive Colorimetric Detection of Hydrogen Peroxide and Glucose. Macromolecules 2011, 44, 429-431. [CrossRef]

11. Takahashi, S.; Anzai, J.-I. Phenylboronic Acid Monolayer-Modified Electrodes Sensitive to Sugars. Langmuir 2005, 21, 5102-5107. [CrossRef]

12. Li, J.; Wang, Z.; Li, P.; Zong, N.; Li, F. A Sensitive Non-enzyme Sensing Platform for Glucose Based on Boronic Acid-diol Binding. Sens. Actuators B 2012, 161, 832-837. [CrossRef]

13. Gao, P.; Wang, Z.; Yang, L.; Ma, T.; Yang, L.; Guo, Q.; Huang, S. A Glucose-responsive pH-switchable Bioelectrocatalytic Sensor Based on Phenylboronic Acid-diol Specificity. Electrochim. Acta 2015, 151, 370-377. [CrossRef]

14. Zhang, L.; Zhang, Z.-Y.; Liang, R.-P.; Li, Y.-H.; Qiu, J.-D. Boron-Doped Graphene Quantum Dots for Selective Glucose Sensing Based on the "Abnormal" Aggregation-Induced Photoluminescence Enhancement. Anal. Chem. 2014, 86, 4423-4430. [CrossRef] [PubMed]

15. Wannajuk, K.; Jamkatoke, M.; Tuntulani, T.; Tomapatanaget, B. Highly Specific-glucose Fluorescence Sensing Based on Boronic Anthraquinone Derivatives via the GOx Enzymatic Reaction. Tetrahedron 2012, 68, 8899-8904. [CrossRef]

16. Yan, J.; Fang, H.; Wang, B. Boronolectins and Fluorescent Boronolectins: An Examination of the Detailed Chemistry Issues Important for the Design. Med. Res. Rev. 2005, 25, 490-520. [CrossRef] [PubMed]

17. Sun, X.; Stagon, S.; Huang, H.; Chen, J.; Lei, Y. Functionalized Aligned Silver Nanorod Arrays for Glucose Sensing through Surface Enhanced Raman Scattering. RSC Adv. 2014, 4, 23382-23388. [CrossRef]

18. Li, S.; Zhou, Q.; Chu, W.; Zhao, W.; Zheng, J. Surface-enhanced Raman Scattering Behaviour of 4-mercaptophenyl Boronic Acid on Assembled Silver Nanoparticles. Phys. Chem. Chem. Phys. 2015, 17, 17638-17645. [CrossRef] [PubMed]

19. Torul, H.; Ciftci, H.; Dudak, F.C.; Adguzel, Y.; Kulah, H.; Boyac, I.H.; Tamer, U. Glucose Determination Based on a Two Component Self-assembled Monolayer Functionalized Surface-enhanced Raman Spectroscopy (SERS) Probe. Anal. Methods 2014, 6, 5097-5104. [CrossRef]

20. Gupta, V.K.; Atar, N.; Yola, M.L.; Eryılmaz, M.; Torul, H.; Tamer, U.; Boyacı, İ.H.; Üstündağ, Z. A Novel Glucose Biosensor Platform Based on Ag@AuNPs Modified Graphene Oxide Nanocomposite and SERS Application. J. Colloid Interface Sci. 2013, 406, 231-237. [CrossRef]

21. Pham, X.-H.; Shim, S.; Kim, T.-H.; Hahm, E.; Kim, H.-M.; Rho, W.-Y.; Jeong, D.H.; Lee, Y.-S.; Jun, B.-H. Glucose Detection Using 4-mercaptophenyl Boronic Acid-incorporated Silver Nanoparticles-embedded Silica-coated Graphene Oxide as a SERS Substrate. BioChip J. 2017, 11, 46-56. [CrossRef]

22. Sooraj, K.P.; Ranjan, M.; Rao, R.; Mukherjee, S. SERS Based Detection of Glucose with Lower Concentration than Blood Glucose Level Using Plasmonic Nanoparticle Arrays. Appl. Surf. Sci. 2018, 447, 576-581. [CrossRef] 
23. Syamala Kiran, M.; Itoh, T.; Yoshida, K.-I.; Kawashima, N.; Biju, V.; Ishikawa, M. Selective Detection of HbA1c Using Surface Enhanced Resonance Raman Spectroscopy. Anal. Chem. 2010, 82, 1342-1348. [CrossRef] [PubMed]

24. Harper, M.M.; McKeating, K.S.; Faulds, K. Recent Developments and Future Directions in SERS for Bioanalysis. Phys. Chem. Chem. Phys. 2013, 15, 5312-5328. [CrossRef] [PubMed]

25. Gong, X.; Bao, Y.; Qiu, C.; Jiang, C. Individual Nanostructured Materials: Fabrication and Surface-enhanced Raman Scattering. Chem. Commun. 2012, 48, 7003-7018. [CrossRef] [PubMed]

26. Wu, D.-Y.; Li, J.-F.; Ren, B.; Tian, Z.-Q. Electrochemical Surface-enhanced Raman Spectroscopy of Nanostructures. Chem. Soc. Rev. 2008, 37, 1025-1041. [CrossRef] [PubMed]

27. Schlücker, S. Surface-Enhanced Raman Spectroscopy: Concepts and Chemical Applications. Angew. Chem. Int. Ed. 2014, 53, 4756-4795. [CrossRef] [PubMed]

28. Shafer-Peltier, K.E.; Haynes, C.L.; Glucksberg, M.R.; Van Duyne, R.P. Toward a Glucose Biosensor Based on Surface-Enhanced Raman Scattering. JACS 2003, 125, 588-593. [CrossRef]

29. Lyandres, O.; Yuen, J.M.; Shah, N.C.; VanDuyne, R.P.; Walsh, J.T.; Glucksberg, M.R. Progress Toward an in vivo Surface-Enhanced Raman Spectroscopy Glucose Sensor. Diabetes Technol. Ther. 2008, 10, 257-265. [CrossRef]

30. Bull, S.D.; Davidson, M.G.; van den Elsen, J.M.H.; Fossey, J.S.; Jenkins, A.T.A.; Jiang, Y.-B.; Kubo, Y.; Marken, F.; Sakurai, K.; Zhao, J.; et al. Exploiting the Reversible Covalent Bonding of Boronic Acids: Recognition, Sensing, and Assembly. Acc. Chem. Res. 2013, 46, 312-326. [CrossRef]

31. Hansen, J.S.; Christensen, J.B.; Petersen, J.F.; Hoeg-Jensen, T.; Norrild, J.C. Arylboronic Acids: A Diabetic Eye on Glucose Sensing. Sens. Actuators B 2012, 161, 45-79. [CrossRef]

32. Nishiyabu, R.; Kubo, Y.; James, T.D.; Fossey, J.S. Boronic Acid Building Blocks: Tools for Sensing and Separation. Chem. Commun. 2011, 47, 1106-1123. [CrossRef] [PubMed]

33. Ye, J.; Chen, Y.; Liu, Z. A Boronate Affinity Sandwich Assay: An Appealing Alternative to Immunoassays for the Determination of Glycoproteins. Angew. Chem. Int. Ed. 2014, 53, 10386-10389. [CrossRef] [PubMed]

34. Gu, X.; Wang, H.; Schultz, Z.D.; Camden, J.P. Sensing Glucose in Urine and Serum and Hydrogen Peroxide in Living Cells by Use of a Novel Boronate Nanoprobe Based on Surface-Enhanced Raman Spectroscopy. Anal. Chem. 2016, 88, 7191-7197. [CrossRef]

35. Hu, S.; Jiang, Y.; Wu, Y.; Guo, X.; Ying, Y.; Wen, Y.; Yang, H. Enzyme-Free Tandem Reaction Strategy for Surface-Enhanced Raman Scattering Detection of Glucose by Using the Composite of Au Nanoparticles and Porphyrin-Based Metal-Organic Framework. ACS Appl. Mater. Interfaces 2020, 12, 55324-55330. [CrossRef]

36. Zhao, M.; Huang, Y.; Peng, Y.; Huang, Z.; Ma, Q.; Zhang, H. Two-dimensional Metal-organic Framework Nanosheets: Synthesis and Applications. Chem. Soc. Rev. 2018, 47, 6267-6295. [CrossRef] [PubMed]

37. Pham, X.-H.; Lee, M.; Shim, S.; Jeong, S.; Kim, H.-M.; Hahm, E.; Lee, S.H.; Lee, Y.-S.; Jeong, D.H.; Jun, B.-H. Highly Sensitive and Reliable SERS Probes Based on Nanogap Control of a Au-Ag Alloy on Silica Nanoparticles. RSC Adv. 2017, 7, 7015-7021. [CrossRef]

38. Shim, S.; Pham, X.-H.; Cha, M.G.; Lee, Y.-S.; Jeong, D.H.; Jun, B.-H. Size Effect of Gold on Ag-coated Au Nanoparticle-embedded Silica Nanospheres. RSC Adv. 2016, 6, 48644-48650. [CrossRef]

39. Bong-Hyun, J.; Gunsung, K.; Sinyoung, J.; Suk, N.M.; Xuan-Hung, P.; Homan, K.; Myung-Haing, C.; Jong-Ho, K.; Yoon-Sik, L.; Hong, J.D. Silica Core-based Surface-enhanced Raman Scattering (SERS) Tag: Advances in Multifunctional SERS Nanoprobes for Bioimaging and Targeting of Biomarkers. Bull. Korean Chem. Soc. 2015, 36, 963-978. [CrossRef]

40. Pham, X.-H.; Hahm, E.; Kim, T.H.; Kim, H.-M.; Lee, S.H.; Lee, Y.-S.; Jeong, D.H.; Jun, B.-H. Enzyme-catalyzed Ag Growth on Au Nanoparticle-assembled Structure for Highly Sensitive Colorimetric Immunoassay. Sci. Rep. 2018, 8, 6290. [CrossRef] [PubMed]

41. Pham, X.-H.; Hahm, E.; Kim, T.H.; Kim, H.-M.; Lee, S.H.; Lee, S.C.; Kang, H.; Lee, H.-Y.; Jeong, D.H.; Choi, H.S.; et al. Enzyme-amplified SERS Immunoassay with Ag-Au Bimetallic SERS Hot Spots. Nano Res. 2020, 13, 3338-3346. [CrossRef]

42. Pham, X.-H.; Hahm, E.; Kang, E.; Ha, Y.N.; Lee, S.H.; Rho, W.-Y.; Lee, Y.-S.; Jeong, D.H.; Jun, B.-H. Gold-silver Bimetallic Nanoparticles with a Raman Labeling Chemical Assembled on Silica Nanoparticles as an Internal-standard-containing Nanoprobe. J. Alloys Compd. 2019, 779, 360-366. [CrossRef]

43. Pham, X.-H.; Hahm, E.; Kang, E.; Son, B.S.; Ha, Y.; Kim, H.-M.; Jeong, D.H.; Jun, B.-H. Control of Silver Coating on Raman Label Incorporated Gold Nanoparticles Assembled Silica Nanoparticles. Int. J. Mol. Sci. 2019, 20, 1258. [CrossRef]

44. Pham, X.-H.; Hahm, E.; Huynh, K.-H.; Son, B.S.; Kim, H.-M.; Jeong, D.H.; Jun, B.-H. 4-Mercaptobenzoic Acid Labeled Gold-SilverAlloy-Embedded Silica Nanoparticles as an Internal Standard Containing Nanostructures for Sensitive Quantitative Thiram Detection. Int. J. Mol. Sci. 2019, 20, 4841. [CrossRef] [PubMed]

45. Yang, D.; Afroosheh, S.; Lee, J.O.; Cho, H.; Kumar, S.; Siddique, R.H.; Narasimhan, V.; Yoon, Y.-Z.; Zayak, A.T.; Choo, H. Glucose Sensing Using Surface-Enhanced Raman-Mode Constraining. Anal. Chem. 2018, 90, 14269-14278. [CrossRef]

46. Ly, N.H.; Lam, A.T.N.; Dinh Bao, N.; Kwark, Y.-J.; Joo, S.W. Glucose-induced and Fructose-induced Deboronation Reaction of 4-mercaptophenylboronic Acid Assembled on Silver Investigated by Surface-enhanced Raman Scattering. Surf. Interface Anal. 2017, 49, 495-502. [CrossRef]

47. Lippert, A.R.; Van de Bittner, G.C.; Chang, C.J. Boronate Oxidation as a Bioorthogonal Reaction Approach for Studying the Chemistry of Hydrogen Peroxide in Living Systems. Acc. Chem. Res. 2011, 44, 793-804. [CrossRef] [PubMed]

48. Liu, B.; Hu, R.; Deng, J. Characterization of Immobilization of an Enzyme in a Modified Y Zeolite Matrix and Its Application to an Amperometric Glucose Biosensor. Anal. Chem. 1997, 69, 2343-2348. [CrossRef] [PubMed] 
49. Laughlin, M.R. Normal Roles for Dietary Fructose in Carbohydrate Metabolism. Nutrients 2014, 6, 3117-3129. [CrossRef] [PubMed]

50. Kawasaki, T.; Akanuma, H.; Yamanouchi, T. Increased Fructose Concentrations in Blood and Urine in Patients with Diabetes. Diabetes Care 2002, 25, 353-357. [CrossRef] [PubMed]

51. Höller, R.P.M.; Jahn, I.J.; Cialla-May, D.; Chanana, M.; Popp, J.; Fery, A.; Kuttner, C. Biomacromolecular-Assembled Nanoclusters: Key Aspects for Robust Colloidal SERS Sensing. ACS Appl. Mater. Interfaces 2020, 12, 57302-57313. [CrossRef] [PubMed] 